Volume 5 Oktober, 2020 (151-157)

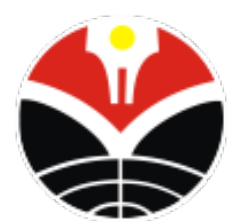

JTIKOR (Jurnal Terapan Ilmu Keolahragaan)

http://eiournal.upi.edu/index.php/JTIKOR

https://doi.org/10.17509/itikor.v5i2.31255

\title{
Efektivitas Masase dan Terapi Latihan Fleksibilitas Terhadap Pemulihan Rasa Nyeri dan Kelentukan Ekstremitas Bawah Pada Atlet Bulutangkis
}

\section{Basiran ${ }^{\bowtie}$, Ridha Mustaqim, Dery Rimasa}

Program Studi Pendidikan Kepelatihan Olahraga, Fakultas Pendidikan Olahraga dan Kesehatan, Universitas Pendidikan Indonesia, Jawa Barat, Indonesia

\section{Info Artikel}

\section{Kata Kunci:}

Masase, Fleksibilitas, Ekstremitas

Bawah, Bulutangkis

Keywords:

Massage, Flexibility, Lower

Extremity, Badminton

J1. Dr. Setiabudhi No. 299

Bandung 40154 No. Telp. (022)

2013163

E-mail: basiran@upi.edu

\begin{abstract}
Abstrak
Penelitian ini bertujuan untuk mengetahui efektivitas masase dan terapi latihan fleksibilitas terhadap pemulihan rasa nyeri dan kelentukan ekstremitas bawah pada atlet bulutangkis. Penelitian ini merupakan penelitian pre-eksperimental. Metode yang digunakan adalah One-group Pretest-posttest Design. Populasi penelitian adalah anggota aktif UKM Bulutangkis Universitas Pendidikan Indonesia sebanyak 14 orang. Teknik sampling yang digunakan dalam penelitian ini adalah Purposive Sampling. Instrumen yang digunakan adalah sit and reach box dan skala numerik nyeri. Teknik analisis yang dilakukan adalah analisis uji-t. Hasil penelitian ini menunjukkan bahwa terdapat efektivitas masase terhadap pemulihan rasa nyeri ekstermitas bawah pada atlet Bulutangkis dengan nilai t-hitung 14,05, rerata 4,54 dan taraf interval kepercayaan 95\% dengan nilai terendah 3,85 dan nilai tertinggi 5,23. Terdapat efektivitas latihan fleksibilitas terhadap peningkatan kelentukan ekstremitas bawah pada atlet Bulutangkis dengan nilai t-hitung 5,67, rerata 2,45 dan taraf interval kepercayaan $95 \%$ dengan nilai terendah 1,53 dan nilai tertinggi 3,38 . Berdasarkan hasil penelitian di atas menunjukkan bahwa masase dan latihan fleksibilitas mampu memberikan perubahan terhadap rasa nyeri dan kelentukan extremitas bawah pada atlet.
\end{abstract}

\begin{abstract}
This study aims to determine the effectiveness of massage and flexibility training therapy for the relief of pain and flexibility in the lower extremities in badminton athletes. This research is pre-experimental. The method used is the One-group pretestposttest design. The study population is an active member of the Badminton Student Activity Units, Universitas Pendidikan Indonesia as many as 14 people. The sampling technique used in this study is Saturated Sampling or Total. The instruments used were the sit and reach box and a numerical scale of pain. The analysis technique used is t-test analysis. The results of this study indicate that there is effectiveness of massage on the recovery of lower extremity pain in badminton athletes with a t-count of 14.04, a mean of 4.53 and a confidence interval of $95 \%$ with the lowest value of 3.84 and the highest value of 5.22. There is the effectiveness of flexibility training to increase the flexibility of the lower extremities in badminton athletes with a t-count of 5.66, a mean of 2.44 and a confidence interval of $95 \%$ with the lowest value of 1.52 and the highest value of 3.37. Based on the results of the above research, it shows that massage and flexibility exercises can provide changes to pain and flexibility in the lower extremities in athletes or active members of the Badminton Student Activity Units, Universitas Pendidikan Indonesia.
\end{abstract}

Copyright (C) 2020, Authors 


\section{PENDAHULUAN}

Perkembangan olahraga saat ini mengalami kemajuan yang pesat baik dari ilmu pengetahuan dan teknologi, manajemen bisnis, dan program pelatihan. Semua pelatih yang berkecimpung di dunia olahraga memiliki program pelatihan. Padahal faktanya tidak semua pelatih membuat rencana tahunan untuk atletnya atau program latihan yang salah sehingga banyak atlet yang mengalami cedera baik pada otot, persendian, ligamen maupun tulang.

Semua aktivitas manusia, termasuk olahraga, penuh dengan risiko atau bahaya. Seiring dengan peningkatan aktivitas olahraga, risiko atau bahaya juga meningkat (Sukarmin, 2015). Sekecil apapun resiko atau bahayanya yang timbul dalam kegiatan olah raga, jika diabaikan atau tidak ditangani secara serius dan tidak dapat dikendalikan sepenuhnya maka akan menimbulkan kecelakaan dengan segala akibat yang merugikan bagi manusia, termasuk cedera.

Cedera adalah cedera atau kerusakan fungsi tubuh akibat olah raga atau aktivitas kerja. Cedera olahraga adalah cedera pada sistem integumen, otot, dan kerangka yang disebabkan oleh aktivitas olahraga. Secara umum cedera adalah segala kerusakan atau cedera yang diderita atau diderita oleh seseorang (Sukarmin, 2015). Dengan demikian cedera olahraga dapat diartikan sebagai cedera yang terjadi ketika seseorang melakukan aktivitas fisik, latihan, atau pertandingan olahraga. Cedera merupakan kendala bagi atlit atau atlit untuk berhenti berolahraga atau berlatih selama beberapa waktu dan sampai seseorang pensiun dini untuk penampilan olahraganya.

Bulu tangkis merupakan salah satu olahraga yang cukup terkenal di dunia. Olahraga ini menarik minat semua kelompok umur, berbagai tingkat keahlian baik pria maupun wanita, hal ini dibuktikan dengan munculnya klub bulu tangkis mulai dari tingkat daerah hingga nasional.

Bulutangkis merupakan olah raga yang dimainkan dengan menggunakan net, raket, shuttlecock dengan teknik memukul yang bervariasi dari relatif lambat sampai sangat cepat disertai dengan gerakan yang menipu. Dari latihan taktis bagaimana menyerang dan bertahan, jangan lupa dukung semuanya ditambah latihan fisik dan mental untuk menciptakan pemain berkualitas. Ada hubungan positif antara kekuatan lengan, kekuatan perut, kekuatan tungkai, kekuatan cengkeraman, fleksibilitas dengan kinerja keterampilan pemain bulu tangkis (Mahulkar, 2016). Bulutangkis juga memerlukan ledakan gerakan singkat dengan perubahan arah yang tiba-tiba, yang menempatkan pemain pada risiko cedera traumatis non-kontak pada sendi dan unit tendon otot (Pardiwala et al., 2020). menunjukkan insiden cedera $4,1 \%$, dengan $82,9 \%$ cedera ekstremitas bawah. 128 cedera terjadi di sendi pergelangan kaki yang merupakan $62 \%$ dari semua cedera yang didokumentasikan (Krøner et al., 1990).

Di belakang spar, ada cedera saat latihan. Dalam bulu tangkis resiko cedera sering terjadi saat menyerang, bertahan, dan tricking dalam waktu yang singkat dengan kecepatan maksimal, tentunya masih banyak kemungkinan terjadinya cedera seperti pergelangan kaki, paha belakang, dan berkurangnya kelenturan pada bagian pinggang. Sebagian besar cedera terjadi di ekstremitas bawah, terutama di lutut dan pergelangan kaki (Jørgensen \& Winge, 1990). Banyak yang mengalami keluhan nyeri menurun dan kelenturan pada ekstremitas bawah, terutama pada sendi hamstring dan pinggul. Selain itu, terdapat 11 pasien cedera tendon Achilles yang membutuhkan perawatan di rumah sakit (Shariff et al., 2009). Dalam penyelidikan pola cedera muskuloskeletal yang dialami oleh pemain bulu tangkis Malaysia, mereka menyimpulkan bahwa sebagian besar cedera terjadi selama latihan $(86,6 \%)$. Cedera yang diderita paling sering di sekitar lutut dan terkait dengan cedera yang berlebihan, tanpa satu pun episode traumatis yang dapat diatribusikan. Mereka mencatat insiden yang lebih tinggi di antara pemain yang lebih muda tetapi tidak ada perbedaan di antara jenis kelamin. Dalam penelitian retrospektif mereka, mereka mencatat bahwa $63 \%$ cedera melibatkan 
tungkai bawah dengan sifat cedera yang berlebihan (36\%), ketegangan $(30,9 \%)$, dan keseleo (26\%). Mereka mencatat total 10 cedera parah dalam masa studi dua setengah tahun. Ini termasuk ruptur tendon Achilles, robekan ligamen anterior, robekan meniscal, dan fraktur metatarsal. Tidak ada cedera parah yang dilaporkan untuk ekstremitas atas atau lokasi anatomi lainnya. Sebuah studi longitudinal tentang cedera bulu tangkis di antara pemain tingkat nasional Jepang mengungkapkan tingkat cedera per pemain per 1000 jam berkisar antara 0,9 hingga 5,1. Tingkat cedera selama latihan lebih tinggi pada wanita dibandingkan pria dan meningkat seiring bertambahnya usia. Ada peningkatan yang signifikan dalam tingkat cedera menurut usia dan jenis kelamin wanita. Berdasarkan tingkat keparahan cedera, proporsi cedera adalah cedera ringan $83,8 \%$, cedera minimal $4,1 \%$, cedera sedang $6,8 \%$, dan cedera berat 1,9\% (Miyake et al., 2016).

Karena keterbatasan pengetahuan dan pengetahuan, sebagian besar atlet bulutangkis belum mengetahui tentang bagaimana menangani cedera dan pelatihan pasca cedera atau pijat pasca cedera dan terapi pelatihan fleksibilitas. Oleh karena itu, peneliti ingin meneliti lebih dalam tentang "Efektivitas Pijat dan Fleksibilitas. Terapi Latihan Pemulihan Nyeri dan Fleksibilitas Ekstremitas Di Bawah Pada Atlet Bulutangkis", sehingga diperoleh data dan tingkat pengaruhnya dari hasil penelitian ini.Penelitian ini bertujuan untuk mengetahui efektifitas terapi pijat dan latihan kelenturan untuk menghilangkan nyeri. dan fleksibilitas pada ekstremitas bawah pada atlet bulutangkis.

\section{METODE}

Dalam penelitian eksperimental tentunya memiliki karakteristik yang berbeda dengan penelitian lainnya yaitu Peneliti aktif memanipulasi variabel bebas (Fraenkel et al., 2012). Tempat penelitian ini dilaksanakan di FPOK UPI. Populasi yang digunakan dalam penelitian ini adalah seluruh anggota aktif UKM Bulutangkis UPI. Teknik total sampling adalah teknik sampling yang sempurna karena tidak ada alasan untuk menganggap total sampling menyimpang (Hadi, 2019).

Desain penelitian yang digunakan dalam penelitian ini adalah pre-experimental dengan rancangan One Group Pretest-Posttest Design, yaitu terdiri atas satu kelompok, tanpa adanya kelompok kontrol. Proses penelitian dilaksanakan dalam tiga tahap yaitu, pretest, perlakuan, dan posttest. Hasil dari perlakuan yaitu perbedaan antara nilai pretest dan posttest. Rancangan penelitian One Group PretestPosttest Design dapat digambarkan sebagai berikut:

\begin{tabular}{|crrr|}
\hline Pretest & $\mathrm{X} 1$ & Posttest \\
$\mathrm{A} 1$ & $\mathrm{~B} 1$ \\
& & & \\
\hline Pretest & $\mathrm{X} 2$ & $\mathrm{~B} 2$ \\
$\mathrm{~A} 2$ & & $\mathrm{~B} 2$ \\
\hline
\end{tabular}

Keterangan :

A1: pretest

$B 1:$ posttest

A2: pretest

B2 : posttest

X1 : perlakuan masase dan perlakuan latihan fleksibilitas

$X 2$ : pemulihan rasa nyeri dan kelentukan ekstremitas bawah.

Dalam rancangan penelitian ini terdapat dua variabel bebas dan dua variabel terikat. Variabel bebas adalah implementasi masase dan terapi latihan fleksibilitas. Variabel terikat adalah pemulihan rasa nyeri dan kelentukan ekstremitas bawah.

\section{Partisipan}

Populasi yang digunakan dalam penelitian ini yaitu seluruh anggota UKM Bulutangkis UPI yang masih aktif. Teknik penarikan sampel dalam penelitian ini adalah total sampling. Sampel yang diambil dalam penelitian ini adalah seluruh anggota UKM Bulutangkis UPI yang masih aktif sebanyak 14 orang.

\section{Instrumen}

Instrumen penelitian dalam penelitian ini dilakukan dengan pemeriksaan fisik dan hasil pengukuran yang tercatat. Tata urutan pengumpulan data. Instrumen yang digunakan 
adalah alat pengukur Skala Numerik Nyeri,Sit And Reach dan stopwatch digunakan untuk mengukur waktu pada saat latihan.

\section{Prosedur}

Prosedur penelitian yaitu diawali dengan pengukuran pretest, kemudian diberikan perlakuan terapi masase satu kali yang dilakukan selama 20 menit. Pemberian terapi latihan dilakukan dengan waktu selama 20 menit. Dilanjutkan dengan pengambilan posttest pada subjek penelitian. Instrumen penelitian adalah alat bantu dan fasilitas yang digunakan dalam proses pengambilan data sehingga akan lebih mudah dan sistematis dalam melakukan pengolahan data.

\section{Analisis Data}

Data yang sudah didapat dari sampel dalam melakukan pre-test dan post-test kemudian dianalisis menggunakan bantuan software SPSS versi 20 yaitu menggunakan uji paired sample ttest. Uji ini untuk menguji apakah terdapat pengaruh. Subjeknya sama tetapi mengalami dua pengukuran atau perlakuan yang berbeda. Terdapat pre-test dan post-test atau terdapat pengukuran tahap 1 dan tahap 2 .

\section{HASIL}

Pada tabel 1 dapat dilihat gambaran hasil pretest dan posttest tingkat nyeri pada terapi massage dan tingkat fleksibilitas pada terapi terapi senam fleksibilitas.

Table 1. Deskripsi Hasil Pretest dan Posttest Tingkat Nyeri Perlakuan Masase dan Eversi (Flexibilitas)

\begin{tabular}{ccccc}
\hline \multirow{2}{*}{ Variable } & \multicolumn{2}{c}{ Pretest } & \multicolumn{3}{c}{ Posttest } \\
\cline { 2 - 5 } & Mean & $\begin{array}{c}\text { Std. } \\
\text { Dev }\end{array}$ & Mean & $\begin{array}{c}\text { Std. } \\
\text { Dev }\end{array}$ \\
\cline { 2 - 5 } Masase Nyeri & 6,13 & 1,4 & 1,6 & 1,76 \\
$\begin{array}{c}\text { Eversi } \\
\text { (Flexibilitas) }\end{array}$ & 10,64 & 2,25 & 13,09 & 2,84 \\
\hline
\end{tabular}

Dari table 2 dapat dilihat analisis akuisisi data massase dan fleksibilitas nyeri. Tabel 2. Efektivitas Massase dan Fleksibilitas Terhadap Nyeri

\begin{tabular}{|c|c|c|c|c|}
\hline \multicolumn{5}{|c|}{ Paired Deference } \\
\hline Pair & Variable & Mean & $\mathrm{t}$ & p \\
\hline $\begin{array}{l}\text { Pair } 1 \\
\end{array}$ & $\begin{array}{l}\text { Massage pain pretest - } \\
\text { posttest }\end{array}$ & 4,53 & 14,09 & 0,000 \\
\hline Pair 2 & $\begin{array}{l}\text { Flexibility pretest - } \\
\text { posttest }\end{array}$ & 2,44 & 5,66 & 0,000 \\
\hline
\end{tabular}

Berdasarkan pair 1 dan 2, hasil analisis statistika menggunakan paired sample t-test, nilai signifikan masase pada rasa nyeri skalanya adalah $0.000(\mathrm{p}<0.05)$ dan nilai signifikan fleksibilitas adalah $0.000(\mathrm{p}<0.05)$.

\section{PEMBAHASAN}

Tujuan penelitian ini adalah untuk mengetahui tingkat keefektifan terapi latihan pijat dan fleksibilitas terhadap keluhan nyeri dan kelenturan ekstremitas bawah pada atlet UKM Bulutangkis UPI. Hasil analisis data menggunakan analisis statistik parametrik (Paired Simple $t$ Test). Pada penelitian ini menunjukkan nilai signifikansi data atau terdapat perbedaan yang signifikan antara pretest dan posttest.

Jika dilihat dari angka rata-rata, hal ini menunjukkan bahwa perlakuan yang dilakukan mampu memberikan perubahan yang lebih baik dibandingkan sebelum pengobatan diberikan. Berdasarkan hasil penelitian diatas menunjukkan bahwa perlakuan yang diberikan yaitu pijat dan latihan kelenturan mampu memberikan perubahan nyeri dan kelenturan ekstremitas bawah pada atlet Bulutangkis UPI yang diukur melalui uji kelenturan dan nyeri. Hasil penelitian menunjukkan bahwa senam pijat dan kelenturan mampu memberikan perubahan yang signifikan dari sebelum dan sesudah perawatan. Dilihat dari hasil penurunan nyeri pada ekstremitas bawah, perlakuan pijat mengalami peningkatan yang lebih baik dibandingkan sebelum dirawat, dengan nilai $\mathrm{t}$ hitung 14,04 , rerata 4,53 dan tingkat interval kepercayaan 95\% dengan nilai terendah sebesar 3,84 dan nilai tertinggi 5,22. Keadaan ini juga terjadi pada penurunan fleksibilitas, perlakuan terapi pelatihan fleksibilitas lebih baik daripada sebelum diberikan perlakuan, dengan nilai $t$ hitung 5,66, rerata 2,44 dan taraf interval 
kepercayaan 95\% dengan nilai terendah 1,52 dan nilai tertinggi 3,37.

Keluhan yang sering dirasakan atlit atau olahragawan setelah melakukan olah raga adalah terjadinya nyeri, cedera dan penurunan fungsi sehingga dapat dimungkinkan karena nyeri tersebut, pergerakan organ tubuh menjadi terbatas. Keadaan ini menunjukkan bahwa aktivitas olahraga memiliki pengaruh yang terkadang dirasakan oleh pelaku olahraga akibat kelelahan dan cedera pada organ tertentu. Bantuan pengaduan biasanya diberikan setelah melaksanakan proses pelatihan melalui kegiatan pendinginan. Variasi pendinginan yang dilakukan oleh pelaku olah raga sangat beragam, sehingga harus disesuaikan dengan kebutuhan dan kondisi serta beban latihan yang dilakukan.

Studi menunjukkan bahwa sebagian besar cedera yang didokumentasikan dihasilkan dari pola penggunaan berlebihan daripada satu episode cedera akut $(77,1 \%$ dalam pertandingan dan $75,4 \%$ dalam praktik). Mereka menyimpulkan bahwa cedera akibat penggunaan berlebihan kira-kira 3 kali lebih umum daripada trauma pada bulu tangkis (Yuki Warashina et al., 2018). Hasil serupa dilaporkan tingkat kejadian cedera secara keseluruhan 5,04 per pemain per 1000 jam (Kaalund et al., 1989). Mereka mencatat bahwa atlet senior elit memiliki tingkat insiden cedera berulang yang tinggi, sementara atlet elit junior dan atlet potensial memiliki tingkat insiden cedera baru yang lebih tinggi. Cedera baru terbanyak adalah strain $(64 \%)$ dan bagian tubuh yang paling sering cedera adalah punggung, bahu, paha dan lutut. Lebih banyak cedera dicatat dalam pelatihan untuk semua kelompok pemain. Insiden keseleo sendi facet lumbal juga tinggi dan menduduki peringkat kedua di antara semua jenis cedera.

Perawatan pijat dan pelatihan fleksibilitas dimaksudkan untuk membantu menenangkan diri setelah melakukan aktivitas olahraga. Proses pendinginan bertujuan untuk mengembalikan kondisi otot dan organ yang bekerja selama latihan kembali ke kondisi sebelum latihan. Pemberian pijatan merupakan suatu hal yang tidak asing lagi dimana melalui pijatan proses pemulihan kondisi otot dapat dilakukan dengan lebih cepat. Selain itu, memberikan proses relaksasi pada otot akan membantu mengembalikan otot ke kondisi semula. Rasa sakit yang Anda rasakan terkadang merupakan akibat dari cedera pada pemain olahraga. Keadaan pemberian perawatan pijat ini akan memberikan rangsangan dan membantu memulihkan kondisi otot yang tidak sesuai dengan kondisi awal.

Hasil analisis terapi pijat di atas dapat memulihkan keluhan otot. Pijat adalah penggunaan berbagai kekuatan dan gerakan untuk manipulasi otot dan jaringan lunak lainnya (Graha \& Priyonoadi, 2012). Dengan merelaksasikan jaringan lunak tubuh, lebih banyak darah dan oksigen dapat mencapai area yang terkena dan mengurangi rasa sakit. Hal ini ditegaskan oleh penelitian lainnya bahwa pijatan mempunyai efek relaksasi dan peregangan otot dan jaringan lunak lain di dalam tubuh sehingga akan mengurangi ketegangan otot, hal ini karena pijatan mempercepat pengosongan dan pengisian dua cairan sehingga Peredaran darah menjadi lancar dan mempercepat pembuangan sisa metabolisme di otot-otot tubuh serta membantu mempercepat pemulihan otot (Basiran, 2009). Sejalan dengan pendapat tersebut, pendapat lain menekankan bahwa secara fisiologis pijat terbukti dapat menurunkan denyut jantung, meningkatkan tekanan darah, meningkatkan sirkulasi darah dan getah bening, mengurangi ketegangan otot, dan meningkatkan ruang sendi serta mengurangi nyeri (Arovah, 2010).

Keadaan ini sama saja dengan memberikan kelenturan dalam proses latihan untuk membantu memulihkan kondisi otot hamstring dan latissimus dorsi. Melakukan peregangan secara teratur di antara aktivitas akan bermanfaat untuk mengurangi ketegangan pada otot, memperlancar peredaran darah dan rasa lelah (Anderson, 2010). Selain itu, senam peregangan dapat meningkatkan sirkulasi darah dan meningkatkan oksigenasi sel. Dengan begitu, latihan peregangan bisa mengurangi gejala kekurangan oksigen sel yang bisa menyebabkan peningkatan asam laktat sehingga menimbulkan rasa nyeri. Pelatihan fleksibilitas 
merupakan teknik dasar yang digunakan untuk meningkatkan rentang gerak (ROM), memberikan terapi pelatihan fleksibilitas pasca cedera diperlukan untuk menjaga mobilitas sendi dan otot serta meminimalkan hilangnya fleksibilitas jaringan dan pembentukan kontraktur (Arovah, 2010).

Kedua perawatan ini memiliki kontribusi yang maksimal untuk pemulihan kondisi organ tubuh setelah melakukan aktivitas olahraga. Pemberian latihan kelenturan pada dasarnya memberikan rangsangan pada otot untuk segera bekerja seperti biasa. Sehingga proses pemulihan yang dimanipulasi oleh penugasan kerja dapat ditangani dengan baik. Namun, memberikan pijatan lebih baik daripada melatih kelenturan karena pijatan langsung mengenai sasaran. Keadaan ini berbeda dengan latihan kelenturan, yang dapat terjadi tidak tepat sasaran pada organ yang terkena. Selain itu, kondisi nyeri yang berlebihan dengan latihan kelenturan tidak akan bekerja secara maksimal karena organ tubuh belum siap untuk berolahraga. Ini menunjukkan bahwa pijatan tepat sasaran dan dapat dilakukan sedini mungkin setelah terjadi cedera. Pemberian latihan kelenturan terkadang tidak bisa langsung diberikan karena harus melihat kondisi awal otot apakah sudah siap untuk diberikan latihan atau belum.

\section{KESIMPULAN}

Secara keseluruhan dalam penelitian ini dapat diambil kesimpulan bahwa, 1) massase memberikan dampak yang efektif terhadap keluhan rasa nyeri ekstremitas bawah pada atlet bulutangkis; 2) terapi latihan fleksibilitas terhadap kelentukan ekstremitas bawah pada atlet bulutangkis.

\section{REFERENSI}

Anderson, B. (2010). Stretching. Shelter Publications, Inc.

Arovah, N. I. (2010). Dasar-dasar Fisioterapi Pada Cedera Olahraga. N/A.

Basiran. (2009). Massage Untuk Atlet. In Jurnal
Kepelatihan Olahraga (Vol. 1, Issue 1).

Fraenkel, J. R., Wallen, N. E., \& Hyun, H. H. (2012). How to Design and Evaluate Research in Education. In The McGraw-Hill Companies (Eighth Edi). The McGraw-Hill Companies. https://doi.org/10.1017/CBO9781107415 324.004

Graha, A. S., \& Priyonoadi, B. (2012). Terapi masase frirage penatalaksanaan cedera pada anggota gerak tubuh bagian bawah. Fakultas Ilmu Keolahragaan Universitas Negeri Yogyakarta, 1-109.

Hadi, S. (2019). Metodologi riset.

Jørgensen, U., \& Winge, S. (1990). Injuries in Badminton. Sports Medicine. https://doi.org/10.2165/00007256199010010-00006

Kaalund, S., Lass, P., Høgsaa, B., \& Nøhr, M. (1989). Achilles tendon rupture in badminton. British Journal of Sports Medicine. https://doi.org/10.1136/bjsm.23.2.102

Krøner, K., Schmidt, S. A., Nielsen, A. B., Yde, J., Jakobsen, B. W., Møller-Madsen, B., \& Jensen, J. (1990). Badminton injuries. British Journal of Sports Medicine, 24(3), 169172. https://doi.org/10.1136/bjsm.24.3.169

Mahulkar, S. S. (2016). Relationship of strength and flexibility with skill performance in badminton players. Internatioanl Journal of Physical Education, Sports and Health.

Miyake, E., Yatsunami, M., Kurabayashi, J., Teruya, K., Sekine, Y., Endo, T., Nishida, R., Takano, N., Sato, S., \& Kyung, H. J. (2016). A prospective epidemiological study of injuries in Japanese national tournament-level badminton players from junior high school to university. Asian Journal of Sports Medicine. https://doi.org/10.5812/asjsm.29637

Pardiwala, D. N., Subbiah, K., Rao, N., \& Modi, R. (2020). Badminton Injuries in Elite Athletes: A Review of Epidemiology and Biomechanics. In Indian Journal of Orthopaedics. 
https://doi.org/10.1007/s43465-020-

00054-1

Shariff, A. H., George, J., \& Ramlan, A. A. (2009). Musculoskeletal injuries among Malaysian badminton players. Singapore Medical Journal.

Sukarmin, Y. (2015). CEDERA OLAHRAGA DALAM PERSPEKTIF TEORI MODEL EKOLOGI. MEDIKORA. https://doi.org/10.21831/medikora.v0i1. 4702

Yuki Warashina, Ryo Ogaki, Akemi Sawai, Hitoshi Shiraki, \& Shumpei Miyakawa. (2018). Risk Factors for Shoulder Pain in Japanese Badminton Players: A Quantitative-Research Survey. Journal of Sports

Science.

https://doi.org/10.17265/2332-

7839/2018.02.003 